\title{
1 Title: Atrazine and amphibians: Data re-analysis and a summary of the controversy
}

Authors: Jason R. Rohr

3 Affiliation: University of South Florida, Department of Integrative Biology, Tampa, FL 33620, USA. jasonrohr@gmail.com

Keywords: amphibian, atrazine, conflicts of interest, disease, endocrine disruptor, frog, herbicide, pesticide, Syngenta, toxicity, US Environmental Protection Agency

9 Abstract. The herbicide atrazine is one of the most commonly used, well studied, and controversial pesticides on the planet. Much of the controversy involves the effects of atrazine on wildlife, particularly amphibians and their non-infectious and infectious diseases, including

12 diseases caused by trematode infections. Here I re-analyze data from authors that were funded

13 by Syngenta Crop Protection, Inc., the company that produces atrazine, and show that even these

14 authors revealed that increasing concentrations of atrazine applied to outdoor mesocosms

15 increases the population growth rate of snails that can transmit trematode parasites to amphibians. These researchers missed this finding in their data because they never calculated

17 population growth rates for the snail populations before they reached a carrying capacity or

18 crashed. These results demonstrate that both Syngenta-funded and non-Syngenta-funded researchers have provided evidence that ecologically relevant concentrations of atrazine are capable of increasing snail populations. Given the controversy surrounding the effects of atrazine on amphibians, I follow this re-analysis with a timeline of some of the most salient

22 events in the history of the atrazine-amphibian controversy. 


\section{Introduction}

The herbicide atrazine [2-chloro-4-(ethylamino)-6-(isopropylamino)-S-triazine] is one of the most widely studied, commonly used, and controversial pesticides on the planet. A search for the term "atrazine" in the search engine Web of Science (conducted on 11/17/2016) produced 11,203 studies. Atrazine was the most commonly used pesticide in the US before it was recently surpassed by the herbicide glyphosate (Roundup ${ }^{\circledR}$ ), which happened because of the advent of genetically modified crops (Grube et al. 2011). Syngenta Crop Protection, Inc., the company that produces atrazine, earns approximately $\$ 2.5$ billion annually from its selective herbicides, of which atrazine is their leading product. Because of it heavy use, as well as its persistence and mobility, atrazine is one of the most common chemical contaminants of freshwater and thus is regularly found in habitats where many freshwater vertebrates, such as fish and amphibians, develop (Rohr et al. 2003, Knutson et al. 2004). Consequently, there has been considerable interest in the effects of atrazine on freshwater vertebrates (e.g. Solomon et al. 2008, Rohr and McCoy 2010b), particularly amphibians because of their permeable skin and global declines (Rohr et al. 2008a, Wake and Vredenburg 2008, Rohr and Raffel 2010, Liu et al. 2013, Raffel et al. 2013, Rohr et al. 2015).

Research on the effects of atrazine on amphibians, however, has been highly contentious. Much of the controversy on atrazine and amphibians involves the effects of atrazine on their non-infectious diseases, such as disruption of the function and development of their endocrine and reproductive systems, and infectious diseases, such as trematode infections. Authors funded by Syngenta Crop Protection have argued that atrazine does not increase populations of snails that can transmit trematodes to amphibians (Baxter et al. 2011), whereas non-Syngenta-funded authors provide data suggesting that atrazine can increase snail populations (Rohr et al. 2008). 
Here, I briefly review the effects of atrazine on amphibians. I then re-analyze the snail data

47 provided by authors that were funded by Syngenta Crop Protection, Inc. (Baxter et al. 2011).

48 Given the controversy surrounding the effects of atrazine on amphibians, I then follow this re-

49 analysis with a timeline of some of the most salient events in the history of the atrazineamphibian controversy.

\section{Background on the Effects of Atrazine on Amphibians}

Atrazine has a variety of effects on freshwater organisms, including fish and amphibians.

54 For example, atrazine has been reported to affect amphibian behaviors crucial for foraging,

55 predator avoidance (Rohr et al. 2003, 2004, Rohr et al. 2009), and desiccation resistance (Rohr

56 and Palmer 2005, 2013). It also impacts growth and timing of metamorphosis (Larson et al.

57 1998, Allran and Karasov 2000, 2001, Boone and James 2003, Rohr et al. 2004, Forson and

Storfer 2006a, Forson and Storfer 2006b).

Given considerable interests in the role of physiology to vertebrate survival and

60

61

62

63

64

65

66

67 conservation (Martin et al. 2010, Rohr et al. 2013b, Madliger et al. 2016), there have been numerous studies on the effects of atrazine on physiology. For example, several studies have investigated atrazine as an 'infodisruptor', defined as a chemical contaminant that disrupts communication within or among organisms, including contaminants that breakdown or interfere with detection or production of chemical signals between senders and receivers or those that affect cell-to-cell communication within organisms (e.g. endocrine disruptors)(Lurling and Scheffer 2007, Rohr et al. 2009). Several studies have shown that atrazine can reduce chemical detection of cues from predators and mates (Moore and Waring 1998, Tierney et al. 2007, 
Ehrsam et al. 2016) and others have shown that it can affect cell-to-cell communication by

69 altering hormones, such as stress hormones (Gabor et al. 2016, McMahon et al. 2017), thyroid

70 hormones (Larson et al. 1998), and sex hormones (Hayes et al. 2003, Hayes 2003). Given that

71 much of the controversy regarding atrazine and amphibians involves its effects on amphibian sex

72 hormones and gonadal development, this topic will be discussed in more detail in the "A

73 Timeline of the Atrazine-Amphibian Controversy" section.

Interest in chemical contaminants causing non-monotonic dose-responses (those with a

75 change in the direction of the slope) (Welshons et al. 2003, McMahon et al. 2011, Vandenberg et responses on several amphibian hormones, including corticosterone, thyroid hormone, and sex hormones (Larson et al. 1998, Hayes et al. 2003, Hayes 2003, Fan et al. 2007, McMahon et al. 2017). Atrazine also regularly has non-monotonic effects on the timing of metamorphosis (Rohr and McCoy 2010b). Although responses on other endpoints have not produced non-monotonic dose responses as regularly, they have regularly produced logarithmic dose responses, where the greatest change in response occurs at low exposure concentrations (Rohr et al. 2004, Rohr et al. 2006b, McMahon et al. 2013, Rohr et al. 2013c), supporting the potency of low concentrations of atrazine.

Given that many factors have been documented to affect amphibian diseases that have

87 been linked to amphibian declines (Li et al. 2013, Liu et al. 2013, Rohr et al. 2013b, McMahon et amphibian immunity and infections. Much of this interest accelerated in 2002 after Kiesecker 
91 increased trematode infections and the limb malformations they cause. Since then, Rohr and

92 colleagues have found additional support for the immunosuppressive effects of atrazine and

93 increases in trematode infections (Rohr et al. 2008b, Rohr et al. 2008c, Raffel et al. 2009,

94 Schotthoefer et al. 2011, Rohr et al. 2015). Additionally, they showed that atrazine increases exposure to trematodes by reducing phytoplankton, which reduces shading and increases the abundance of periphyton, the food source for snails, which are the intermediate host of trematodes (Rohr et al. 2008c, Raffel et al. 2010, Staley et al. 2010, Staley et al. 2011, Halstead et al. 2014). Atrazine exposure, either alone or in mixtures with other chemicals, has also been associated with reduced immunity and increased amphibian viral, flatworm, and roundworm infections (Gendron et al. 1997, Forson and Storfer 2006a, Forson and Storfer 2006b, Hayes et al. 2006, Kerby and Storfer 2009, Koprivnikar 2010). Recently, atrazine exposure was shown to reduce tolerance of chytrid fungal infections that are associated with worldwide amphibian declines (Rohr et al. 2013c). Tolerance is defined as the ability of hosts to reduce damage caused by parasites (Rohr et al. 2010, Sears et al. 2013, Sears et al. 2015). In a 2010 review (Rohr and McCoy 2010b), atrazine exposure was associated with a reduction in 33 of 43 immune 106 function endpoints and with an increase in 13 of 16 infection endpoints. These numbers were an 107 underestimate (Langerveld et al. 2009) and have increased since this review was published (e.g. 108 Koprivnikar 2010, Rohr et al. 2013c). The documented positive relationship between biodiversity and ecosystem functions and 110 services, such as pest and disease control, primary production, and clean water (Dobson et al. 111 2006, McMahon et al. 2012, Staley et al. 2014, Venesky et al. 2014a, Civitello et al. 2015, Cohen 112 et al. 2016, De Laender et al. 2016) and the importance of indirect effects of chemicals mediated 113 by species interactions (Rohr et al. 2006a, Clements and Rohr 2009, Halstead et al. 2014, 
Douglas et al. 2015, Staley et al. 2015) has prompted several researchers to study the effects of atrazine on freshwater communities containing amphibians rather than on isolated amphibian species (de Noyelles et al. 1989, Boone and James 2003, Rohr and Crumrine 2005, Rohr et al.

117 2008c, Halstead et al. 2014). Many of these studies report alterations of amphibian growth and 118 abundance that seem to be caused by atrazine-induced changes in photosynthetic organisms. At 119 ecologically relevant concentrations, atrazine is expected to have a bevy of indirect effects by 120 altering the abundance of phytoplankton, macrophytes, (Herman et al. 1986) and photosynthetic 121 and non-photosynthetic organisms in periphyton (Staley et al. 2010, Staley et al. 2011, Staley et al. 2012, Staley et al. 2015), the latter of which is a primary food source for many tadpole species. However, few of the studies focusing on atrazine and freshwater communities

124 containing amphibians distinguish between direct and indirect effects of atrazine.

Although atrazine generally does not directly cause amphibian mortality at ecologically relevant concentrations (Solomon et al. 2008, Rohr and McCoy 2010b), there are some studies

127 that suggest that it might increase mortality through indirect effects, such as those described in 128 the infectious disease section above. Others suggest that there might be delayed or persistent 129 effects of atrazine on behavior and physiology that can increase mortality risk (Storrs and 130 Kiesecker 2004, Rohr and Palmer 2005, Rohr and McCoy 2010b, Rohr and Palmer 2013). One of the biggest concerns regarding the effects of atrazine on amphibians is that 132 atrazine regularly interacts with other stressors commonly experienced by amphibians, either 133 additively or synergistically. For example, particular climatic conditions, such as increased 134 drying (Rohr et al. 2004, Rohr and Palmer 2005, 2013) and particular biotic conditions, such as 135 parasitism (Rohr and McCoy 2010b) and predation risk (Rohr and Crumrine 2005, Ehrsam et al. 136 2016) can be worsened by atrazine. Atrazine also additively or synergistically interacts with 
137 other common agrochemicals (Rohr et al. 2008c, Halstead et al. 2014). The exception is that

138 global warming will accelerate amphibian development and thus reduce aquatic exposure to

139 atrazine (Rohr et al. 2011). Clearly, there is a need to understand how climate change will affect

140 exposure and toxicity of atrazine and other chemical contaminants (Rohr et al. 2013a, Landis et

141 al. 2014). Nevertheless, interactions among chemical contaminants or between chemical

142 contaminants and non-chemical stressors are unfortunately rarely considered in most ecological

143 risk assessments of chemicals (Rohr et al. 2016, 2017).

145 Methods

146 I extracted the data from Figure 5 of Baxter et al. (2011), which include authors who have

147 historically been funded by Syngenta Crop Protection, Inc. In this experiment, various

148 concentrations of atrazine were applied to outdoor mesocosms containing natural algae,

149 zooplankton, and snails, and snail abundance was tracked through time. Given that initial levels

150 of phosphorous and nitrogen could be depleted through time and were not replenished, these

151 essential elements could become limited and cause algal and snail populations to reach carrying

152 capacities or crash. Hence, I calculated the population growth rate of snails in each tank until an

153 apparent carrying capacity or population crash occurred. Thus, growth rates were calculated for

154 the exponential phase of population growth only. The $30 \mu \mathrm{g} / \mathrm{L}$ treatment was excluded because

155 it did not show the same blocking patterns in dissolved oxygen as the other treatments (see

156 Baxter et al. 2011 Table 3, Rohr et al. 2012). I then plotted the population growth rate estimates

157 against log atrazine concentration. 
159 Results

160 Although not reported in the Baxter et al. (2011) paper, there was a clear increase in snail

161 population exponential growth rates as atrazine concentration increased (Fig. 1). These

162 researchers missed this finding in their data because they never calculated population growth

163 rates for the snail populations before they reached a carrying capacity or crashed. These results

164 demonstrate that both Syngenta-funded (Herman et al. 1986, Baxter et al. 2011) and non-

165 Syngenta-funded researchers (Kiesecker 2002, Rohr et al. 2011, Halstead et al. 2017) have

166 demonstrated that ecologically relevant concentrations of atrazine are capable of increasing snail

167 populations, the source of trematode infections to both amphibians and humans. Given the

168 controversy surrounding the effects of atrazine on amphibians, I now follow this reanalysis with

169 a timeline of some of the most salient events in the history of the atrazine-amphibian

170 controversy.

172 A Timeline of the Atrazine-Amphibian Controversy

173 The early years

175 biology professor at the University of California at Berkeley, was hired by EcoRisk Inc., the

176 consulting company that hired several academic scientists to study atrazine on behalf of

177 Syngenta Crop Protection, Inc. The contract covering Dr. Hayes' research, and that of many of

178 the other scientists Syngenta and EcoRisk hired, made clear that Syngenta retained final say over 
what and whether the scientists could publish. In November of 2000, Hayes quit Syngenta because the company supposedly prevented him from publishing his research showing that levels of atrazine, below the drinking water standard of 3 ppb set by the EPA, caused hermaphroditism and reduced the larynx size of male frogs. According to Hayes, Syngenta and Ecorisk tried to keep him working on atrazine privately, offering him as much as \$2-million in lab support under the auspices of a start-up company owned by his wife. Hayes refused the offer and began replicating the Syngenta-funded studies using independent funds. Soon after breaking ties with EcoRisk and Syngenta, Hayes claims that Syngenta threaten to pull all of UC Berkeley's pharmaceutical and medical funding provided by Syngenta's sister company Novartis Inc. if they tenured Hayes. Despite the ostensible threat, UC Berkeley did eventually tenure Hayes.

At a similar time, in the early 2000s, Krista McCoy began a PhD program at the University of Florida in the laboratory of Dr. Tim Gross, a paid EcoRisk consultant. Krista began a mesocosm study examining the effects of atrazine on amphibians. She came in one morning to discover that Gross had ordered the University of Florida's physical facilities to pick up McCoy's mesocosms with a forklift and move them all directly under the roof line of a large nearby building. McCoy was convinced that the mesocosms were moved so they would receive the entire roof's worth of rain, unrealistically diluting the atrazine. McCoy suspended her atrazine work and switched to laboratory of Dr. Louis Guillette, who confirmed McCoy's story. Dr. Gross was eventually let go from the University of Florida.

In February of 2002, Dr. Jason Rohr, was hired at the University of Kentucky to study the effects of atrazine on amphibians. In April of 2002, soon after Rohr was hired, Dr. Hayes published his studies repeating the work he originally conducted for Syngenta (Hayes et al. 
201

202

203

204

205

206

207

208

209

210

211

212

213

214

215

216

217

218

219

220

221

222

2002b). This work was published in the prestigious Proceedings of the National Academy of

Sciences of the United States of the America (PNAS), and showed that very low levels of atrazine

reduced the larynx size of male frogs and caused male frogs to develop female gonads.

According to Hayes, editors at the prestigious journal Nature then commissioned him to write a follow-up article on field patterns of atrazine and amphibian gonadal abnormalities that was published in Nature in October of 2002 (Hayes et al. 2002a).

In November of 2002, attorneys associated with the Center for Regulatory Effectiveness, the Kansas Corn Growers Association, and the Triazine Network (which receive financial support from Syngenta), argued that Hayes’ studies did not conform with the 2001 Data Quality Act, which prohibits federal agencies from using scientific findings for which there are no established standards. Their petition successfully blocked the US Environmental Protection Agency (EPA) from considering Hayes' work and atrazine was re-registered for use in October of 2003. Ironically, this was the same month that the European Union banned atrazine because of ubiquitous and unpreventable water contamination (Sass and Colangelo 2006). Because of this petition and the Data Quality Act, the EPA had to revise its Environmental Risk Assessment policies, so that hormone disruption would not be a legitimate reason for restricting the use of a chemical until "appropriate testing protocols have been established." (Sass and Devine 2004).

The Data Quality Act has been used widely by industry to block unwanted regulations and as a broader assault on academic freedom (Michaels and Monforton 2005, Rohr and McCoy 2010a).

Since leaving EcoRisk and Syngenta in 2000, the relationship between Hayes and Syngenta representatives became further strained. In 2003, Hayes received a job offer from Duke University and made a second visit to the campus. Duke University is close to Syngenta 
223 Crop Protection headquarters in Greensboro, North Carolina and to Syngenta's research facility

224 in Research Triangle Park, North Carolina. Once Syngenta found out about the offer, they

225 contacted administrators at Duke. Soon after, Duke University withdrew the offer to Hayes.

226 According to subpoenaed documents revealed in a lawsuit (see below), by interfering with

227 Hayes' job offer, Syngenta was attempting to protect their reputation in their local community

228 and among their employees (Howard 2013a). In October of 2003, The Chronicle of Higher

229 Education published a lengthy article on the damaged relationship between Hayes and Syngenta

230 and the price Hayes had to pay to publish his research (Blumenstyk 2003).

\section{Tensions rise}

In November of 2003, there was an organized oral session on the effects of atrazine on

234 amphibians at the North American Society for Environmental Toxicology and Chemistry

235 meetings in Austin, TX. In attendance were Hayes, Rohr, several EPA representatives, and

236 Syngenta- and EcoRisk-funded scientists, including Ronald Kendall, the head of the EcoRisk

237 panel coordinating the investigation of atrazine for Syngenta, and Keith Solomon, a long-time

238 Syngenta-funded academic. There was standing room only. Much to the surprise of all, Hayes

239 presented no data. Rather, he presented only emails ostensibly incriminating the EPA and

240 Syngenta associates of colluding to ensure the re-registration of atrazine. Rohr presented his first

241 talk ever on atrazine immediately after Hayes, quite surprised and intimidated by what just

242 transpired. Because of Hayes' bold presentation, SETAC had to hire extra security for their

243 North American Meetings for several years to come. In December of 2004, Hayes continued to

244 keep a target on Syngenta, publishing an article with colleagues in BioScience reporting that the 
245 single best predictor of whether or not the herbicide atrazine had a significant effect in a study was whether Syngenta funded it (Hayes 2004). That result was highly significant by the usual

248 Council obtained documents revealing that agency officials met privately with Syngenta more than 40 times while evaluating the toxicity of atrazine (Slater 2012). campaign' where they came up with a long list of methods for discrediting him, such as "have his work audited by 3rd party," "ask journals to retract his science," "set trap to entice him to 254 sue," "investigate funding," and "investigate wife" (Howard 2013a, Aviv 2014). They even 255 bought the worldwide web search results for his name so they could better control what the public read about Hayes and atrazine (Howard 2013a, Aviv 2014). Although Hayes suspected

257 much of this, it was not verified until this smear campaign became public in 2012 when thousands of Syngenta documents were subpoenaed in a lawsuit (Howard 2013a) (see below). paper in Nature showing that atrazine increased infectious disease risk in a declining amphibian

261 species by reducing frog immunity and increasing its exposure to the pathogen (Rohr et al.

262 2008c). In November of 2008, in response to an accumulation of papers on atrazine and

263 amphibians, Keith Solomon and colleagues, with financial support from Syngenta, published a

264 paper in Critical Reviews in Toxicology entitled "Effects of atrazine on fish, amphibians, and 265 aquatic reptiles: a critical review" (Solomon et al. 2008). This paper purported to accurately 266 review the effects of atrazine on the behavior, growth, survival, physiology, endocrinology, 
267

268

269

270

271

272

273

274

275

276

277

278

279

280

281

282

gonadal morphology, immunity, and infectious disease risk of amphibians. Rohr, a second year

professor at the University of South Florida, eagerly read the review paper but did not recall the primary literature the same way as it was described by Solomon et al. (2008). Around the same time, Krista McCoy, an eventual postdoctoral research associate in Rohr's laboratory, expressed to Rohr that she too did not agree with Solomon et al.'s depiction of the primary literature on atrazine. Hence, Rohr and McCoy collaborated to quantify the inaccurate representations of primary literature in the Syngenta-funded Solomon et al. (2008) article, as well as conduct their own objective meta-analysis of the literature to set the record straight.

While Rohr and McCoy worked on their analyses, the heat on atrazine continued to build. In August of 2009, The New York Times investigation found that 33 million Americans were exposed to atrazine through drinking water and, later, data from EPA showed that contamination exceeded the federal limit in 9 out of 10 Midwestern states monitoring it. Several of these water districts reported between 9 and 18 times the federal limit, levels linked to birth defects, premature birth, and low birth weight (Slater 2012).

\section{The controversy really escalates in 2010}

In January of 2010, Hayes et al. published an elegant experiment in PNAS (Hayes et al. 2010) where they exposed a laboratory population of all genetically male frogs to low levels of atrazine and showed that these males were both demasculinized (chemically castrated) and completely feminized as adults. Atrazine-exposed genetic males suffered from depressed testosterone, decreased breeding gland size, feminized laryngeal development, suppressed 
288

289

290

291

292

293

294

295

296

297

298

299

300

301

302

303

304

305

306

307

308

309

310

mating behavior, reduced spermatogenesis, and decreased fertility. Additionally, $10 \%$ of these males developed into functional females that copulated with unexposed males and produced viable eggs.

$$
\text { During the early months of 2010, Rohr and McCoy completed their assessment of the }
$$

Solomon et al. (2008) article and set the record straight with their own meta-analysis (Rohr and McCoy 2010b). Rohr and McCoy revealed that the Syngenta-funded review by Solomon et al. (2008) had arguably misrepresented over 50 studies and had 122 inaccurate and 22 misleading statements. Of these 144 seemingly inaccurate or misleading statements, $96.5 \%$ appeared to be beneficial for Syngenta in that they supported the safety of the chemical (Rohr and McCoy 2010a). In addition, Solomon et al. (2008) cast doubts on the validity of $94 \%$ of the 63 presented cases where atrazine had adverse effects, whereas they almost never criticized the 70 cases where there were no effects of atrazine at environmentally relevant concentrations (Rohr and McCoy 2010a). Rohr and McCoy then conducted a qualitative meta-analysis on the same data analyzed by Solomon et al. (2008) and the general conclusions were the same regardless of whether they excluded studies based on clear quality criteria or included all studies (Rohr and McCoy 2010b). They showed that atrazine regularly disrupted the timing of amphibian metamorphosis, reduced size at or near metamorphosis, altered amphibian motor activity and antipredator behaviors, reduced olfactory abilities, diminished immune function, increased infection end points, and altered aspects of gonadal morphology and function and sex hormone concentrations, but did not directly affect amphibian survival (Rohr and McCoy 2010b). These two studies were submitted as companion papers to Environmental Health Perspectives. The meta-analysis was published there (Rohr and McCoy 2010b) but the editor refused to even review the paper on the conflicts of interest, inaccuracies, and bias of the Solomon et al. (2008) 
311 paper. After four additional case where editors did not send the paper out for review in many

312 cases fearing the controversy, Rohr and McCoy put a conservation angle on the conflicts of 313 interest paper and published it in Conservation Letters (Rohr and McCoy 2010a). There was

314 surprisingly little push back from Syngenta on these papers. In fact, according to subpoenaed

315 documents, Syngenta representatives prepared their funded scientists on how to respond to

316 difficult questions about these studies, describing the meta-analysis as a "rigorous and

317 comprehensive review".

In July of 2010, Danielle Ivory of the Huffington Post Investigative Fund reported that

peer-reviewed. Additionally, at least half were conducted by scientists with a financial stake in atrazine (Ivory 2009, 2010). This investigation raised additional concerns over the decisionmaking process on the safety of atrazine.

324 file documenting offensive and potentially embarrassing emails sent by Hayes to Syngenta

325 representatives over the years. In these emails, Hayes had used profanities and sexual taunts, and 326 aggressive, salacious, lewd, and insulting language. The NY Times wrote a story about the 327 emails (Schor 2010) and republished the PDF file

328 (http://www.atrazine.com/amphibians/combined_large_pdf-r-opt.pdf). The emails were also 329 covered by Nature (Dalton 2010). These emails made it clear that the unprofessionalism and 330 questionable decision making was occurring by both parties. Dashka Slater provided the 331 following quote in her Mother Jones article to describe these emails "His [Hayes] irreverence 332 had always been an asset, attracting attention to atrazine just as Rachel Carson's impassioned 
333 lyricism drew attention to DDT. But now irreverence had tipped toward irrationality." (Slater

334 2012). Based on these emails, Syngenta issued a formal ethics complaint filed at the University

335 of California Berkeley. The university's chief counsel ruled that no ethics violation had occurred

336 but admonished both sides to behave.

In 2010, a class-action lawsuit against Syngenta picked up steam. The lawsuit, originally

filed in 2004 by Holiday Shores Sanitary District, grew and eventually included more than 1,000

340 led by Stephen Tillery of the law firm Korein Tillery, LLC, was brought because Midwestern

341 water treatment facilities often could not get atrazine concentrations in their drinking water

342 below the US EPA maximum contaminant level deemed safe for human consumption (3 ppb).

343 Rohr passed on testifying in the case (see below), whereas Hayes did testify and Stephen Tillery

344 stated that Hayes' work gave them the scientific basis for the lawsuit.

In 2012, the class-action lawsuit filed in 2004 by Holiday Shores Sanitary District that

346 grew into a class action lawsuit with more than 1,000 community water systems in Illinois,

347 Missouri, Kansas, Indiana, Iowa and Ohio vigorously continued until the integrity of an

348 important witness for Korein Tillery (someone other than Hayes) was questioned after illicit

349 behaviors were allegedly uncovered. Soon after, Tillery and associates settled the suit but

350 Syngenta denied all wrongdoing and did not claim any liability. Syngenta paid \$105 million to

351 reimburse more than a thousand Midwestern water utilities for the cost of filtering atrazine from

352 drinking water. When lawyer fees were removed, this amounted to well under $\$ 100,000$ per

353 water treatment plant. 

recruit him as an expert scientist for the case. They offered to pay Rohr generously for his services. Before jumping at the opportunity, Rohr queried Tillery. Rohr asked whether the

357 atrazine problem was not at least partially an issue of how much atrazine was applied in the 358 Midwestern US and that most of the water treatment plants there lacked modern carbon filtration 359 systems necessary to remove the atrazine. Tillery confirmed that this was a major source of the 360 problem. Rohr then made it clear that Syngenta could not control who buys their product, where 361 they apply it, how much they apply, or whether water treatment plants have adequate carbon 362 filtration systems. Hence, Rohr questioned whether the atrazine problem in the Midwestern US 363 was an EPA enforcement issue and whether the EPA, not Syngenta, should be sued. Tillery 364 agreed with all the logic but claimed that he could not sue the EPA. Rohr, however, made it 365 clear to Tillery that he could sue the EPA because the Natural Resource Defense Council sues 366 the EPA all the time; law firms just cannot sue the EPA for money. Rohr politely declined the 367 offer to be an expert witness, worried that the lawsuit was misdirected at the entity with the 368 deepest pockets. In November of 2010, Rohr gave a seminar on atrazine at Illinois State University the 370 year after Hayes gave his seminar there. Illinois State University is not far from Syngenta's US

371 headquarters in Illinois. In preparation for the seminar, Illinois State University's Department of

372 Biology hired a security guard to staff the talk. Syngenta sent an attorney in a three piece suit

373 that was frisked by the security guard to check for recording devices. The attorney took copious 374 notes throughout the talk. 
After the flurry of papers published by Rohr's laboratory between 2008 and the

376

377

378

379

380

381

382

383

384

385

386

387

388

beginning of 2011 on atrazine and chlorothalonil, two pesticides produced by Syngenta, Rohr started receiving pushback from the Director of the facility where Rohr conducted his outdoor tank (mesocosm) experiments on agrochemicals. Rohr collaborated with Dr. Steven Johnson of the University of Florida's Gulf Coast Research and Education Center (GCREC), which was just 45 minutes from the University of South Florida where Rohr is employed. This collaboration allowed Rohr to have his tank facility at GCREC. The Director of the GCREC's wife worked for Syngenta at the time. Rohr and Johnson did not face any challenges until they started publishing their findings. Johnson surprisingly found out that he was being forced out of the GCREC back to the main campus of the University of Florida in Gainesville. Given that Johnson was no longer at the GCREC, the Director of the GCREC told Rohr he also had to leave because his collaborator was no longer at the facility. Rohr resourcefully looked to find another collaborator at the GCREC so he could continue his work there. He found two faculty members other than Johnson that wanted to collaborate but the Director of the GCREC blocked both collaborations and eventually told all GCREC faculty that they could not collaborate with Rohr or conduct any pesticide-related toxicological research, stifling their academic freedoms. It took Rohr several years to find a location and setup another tank facility, a major impediment to his ecotoxicological research on atrazine and other agrochemicals.

\section{Revelations from the lawsuit and the EPA scientific advisory panel}

The most important outcome of the lawsuit was not the settlement but the Syngenta documents that became "unsealed" by the Madison County Circuit Court in response to a 
397 Freedom of Information Act request by the courageous investigative reporting conducted by

398 Clare Howard of 100Reporters. The 1,000 or so pages of memos, notes, and e-mails that Clare received exposed Syngenta's tactics and efforts to conceal and discredit the science on atrazine. They revealed that Hayes was not paranoid after all and that Syngenta was indeed behind a campaign to smear him and his reputation. The subpoenaed documents revealed that one of the company's strategies had been to "purchase 'Tyrone Hayes' as a search word on the internet, so that any time someone searches for Tyrone's material, the first thing they see is our material."

404 Syngenta later also purchased the phrases "amphibian hayes," "atrazine frogs," and "frog 405 feminization" and searching online for "Tyrone Hayes" for years until the settlement brought up an advertisement that said, "Tyrone Hayes Not Credible." The documents revealed that

407 Syngenta invested in a multi-million dollar campaign to protect atrazine profits, which included hiring a detective agency to investigate scientists on a federal advisory panel, looking into the personal life of a judge, and discrediting and distracting Hayes. These documents also listed other strategies directed at Hayes, such as "commissioning a psychological profile", "have his work audited by 3rd party", "ask journals to retract", "set trap to entice him to sue". "investigate

412 funding", "investigate wife", "tracking him at speaking engagements", "baiting him through

413 emails", and interfering with Hayes' job offer at Duke. Syngenta would send representative to

414 talks Hayes gave to question and embarrass him. Rohr too had similar experiences. The 415 documents also revealed that Syngenta kept a list of 130 people and groups it could recruit as 416 experts, including academics, without disclosing ties to the company (see

417 https://www.documentcloud.org/documents/686401-100reporters-syngenta-clare-howard-

418 investigation.html for the list). It often paid members of this group to write opeds and other 419 articles. According to Jayne Thompson from Jayne Thompson \& Associates, a public relations 
420 firm hired to work on the Syngenta campaign, "These are great clips for us because they get out

421 some of our messages from someone who comes off sounding like an unbiased expert. Another

422 strength is that the messages do not sound like they came from Syngenta." Clare Howard

423 summarizes her investigative reporting on these documents in a ground breaking article

424 published in June of 2013 in a 100Reporters (Howard 2013a). Unfortunately, these documents

425 did not get considerable press until February of 2014 when the more well-known magazine The

426 New Yorker released an article on atrazine, Hayes, and the uncovered Syngenta documents (Aviv

427 2014). The original New Yorker article inexplicably did not acknowledge any of Clare's seminal

428 investigative work (Aviv 2014).

Ironically, as the class-action lawsuit was being settled, so too were the policy decisions on the safety of atrazine to amphibians. The EPA had convened a scientific advisory panel to assess the effects of atrazine on amphibians and originally offered Rohr to be a member on this panel. The EPA then rescinded this offer because Rohr's work would serve too prominently in

USEPA concluded that "exposure to atrazine at concentrations ranging from 0.01 to 100

436 (which included survival, growth, metamorphosis, and sexual development)" (p. 60) and that the

437 "level of concern for effects on aquatic plant communities... was lower than the atrazine concentration observed to produce significant direct or indirect effects on invertebrates, fish,

439 and amphibians" (USEPA 2012), which would eliminate further assessments of atrazine's

440 impacts on amphibians despite significant effects at these concentrations in other studies. The

441 EPA's conclusion that atrazine does not adversely affect amphibians, however, was based on a

442 single published study that was funded by Syngenta, despite there being hundreds of studies on 
443 atrazine. Several members of the scientific advisory panel argued that a decision on the safety of

444 atrazine should not be made based on any single study, especially one funded by the company

445 with a financial stake in the product. In fact, after finishing her work on the scientific advisory

446 panel, Boone collaborated with Rohr and other colleagues to write articles denouncing the use of

447 a single industry-funded study to evaluate the adverse effects of atrazine, or for that matter, any

448 chemical (Boone et al. 2014, Boone and Rohr 2015).

450 Television primetime news show similar to 60 Minutes, 20/20, or Dateline in the US

451 (http://globalnews.ca/video/1252483/full-story-pesticide-peril). The story was produced by Gil

452 Shochat and summarizes the story of the amphibian-atrazine controversy. It also offers an

453 interview with a former Syngenta staffer who describes Syngenta's internal strategies for

454 discrediting scientists.

\section{Three additional surprising twists}

458 did not have sufficient funds to pay for his vertebrate animal care. Hayes claimed that his lab

459 fees had gone up by $295 \%$ since 2004 , while fees for his colleagues at UC Berkeley had risen by

460 only 15\% (Howard 2013b). The director of the office of laboratory-animal care apparently

461 provided evidence that Hayes was being charged according to standard campus-wide rates that

462 increased for most researchers in recent years. Nevertheless, Hayes recruited Stephen Tillery to 
represent him in a lawsuit against UC Berkeley claiming that his vertebrate animal care fees were essentially preventing him from doing his job. The status of this case is currently unclear.

In 2016, after the damaging press of the unsealed court documents, Syngenta announced that it was set to be acquired by Chinese state-owned ChemChina (Spegele and Chu 2016). However, Syngenta and ChemChina missed the European Union's deadline for submission of antitrust remedies (Blackstone and Drozdiak 2016), raising questions regarding whether they will be able to satisfactorily deal with the antitrust concerns. It remains unclear whether the deal will happen and if the tactics of Syngenta will change if the sale occurs.

In May 2007, the Center for Biological Diversity filed a lawsuit against the EPA for violating the Endangered Species Act by registering and allowing the use of many pesticides without determining whether the chemicals jeopardized endangered species in the San Francisco Bay. A federal court then signed an injunction, imposing interim restrictions on the use of 75 pesticides in the Bay Area. This in turn required that the EPA formally evaluate the effects of those chemicals on endangered species. In June of 2015, the EPA announced that it would analyze the effects of glyphosate (active ingredient in the herbicide Roundup) and atrazine on 1,500 endangered plants and animals (Beyond_Pesticides 2015). Likely as a result of this court order, the EPA re-evaluated atrazine and, apparently in error, released the report online in April of 2016, a presidential election year. This sparked criticism from Syngenta and U.S. lawmakers (Polansek 2016).

In perhaps the most surprising twist of all, the EPA completely reversed its position on the safety of atrazine in this "inadvertently" released reassessment of atrazine. Despite the EPA concluding that atrazine was safe for over four decades, the new and refined risk assessment 
485 (Farruggia et al. 2016) states the following: "Based on the results from hundreds of toxicity

486

487

488

489

490

491

492

493

494

495

496

497

498

499

500

501 studies on the effects of atrazine on plants and animals, over 20 years of surface water monitoring data, and higher tier aquatic exposure models, this risk assessment concludes that aquatic plant communities are impacted in many areas where atrazine use is heaviest, and there is potential chronic risk to fish, amphibians, and aquatic invertebrates in these same locations.

In the terrestrial environment, there are risk concerns for mammals, birds, reptiles, plants and plant communities across the country for many of the atrazine uses. EPA levels of concern for chronic risk are exceeded by as much as 22, 198, and 62 times for birds, mammals, and fish, respectively. For aquatic phase amphibians, a weight of evidence analysis concluded there is potential for chronic risks to amphibians based on multiple effects endpoint concentrations compared to measured and predicted surface water concentrations... average atrazine concentrations in water at or above $5 \mu \mathrm{g} / \mathrm{L}$ for several weeks are predicted to lead to reproductive effects in fish, while a 60 -day average of $3.4 \mu \mathrm{g} / \mathrm{L}$ has a high probability of impacting aquatic plant community primary productivity, structure and function." It remains unclear why the EPA changed its opinion on the safety of atrazine, how the report was "inadvertently released", and what its consequences will be. However, if there is one thing that I have learned about the science and policy decisions on atrazine, it is to expect the unexpected! 
502

503

504

505

506

507

508

509

510

511

512

513

514

515

516

517

518

519

520

521

522

523

524

\section{References}

Allran, J. W., W. H. Karasov. (2000). Effects of atrazine and nitrate on northern leopard frog (Rana pipiens) larvae exposed in the laboratory from posthatch through metamorphosis. Environmental Toxicology and Chemistry 19,2850-2855.

Allran, J. W., W. H. Karasov. (2001). Effects of atrazine on embryos, larvae, and adults of anuran amphibians. Environmental Toxicology and Chemistry 20,769-775.

Aviv, R. (2014). A valuable reputation. The New

Yorker,http://www.newyorker.com/magazine/2014/2002/2010/a-valuable-reputation.

Baxter, L. R., D. L. Moore, P. K. Sibley, et al. (2011). Atrazine does not affect algal biomas or snail populations in micrososm communities at environmentally relevant concentrations. Environmental Toxicology and Chemistry 30,1689-1696.

Beyond_Pesticides. (2015). Atrazine and Glyphosate To Be Analyzed by EPA For Impacts on 1,500 Endangered Species. Daily New Blog. Beyond Pesticides, http://beyondpesticides.org/dailynewsblog/2015/06/atrazine-and-glypohsate-to-beanalyzed-by-epa-for-impacts-on-1500-endangered-species/.

Blackstone, B., N. Drozdiak. (2016). Syngenta and ChemChina Miss EU Deadline for Antitrust Remedies. Pages http://www.wsj.com/articles/syngenta-and-chemchina-miss-euantitrust-deadline-for-merger-1477304119 The Wall Street Journal, New York.

Blumenstyk, G. (2003). The Price of Research: A Berkeley scientist says a corporate sponsor tried to bury his unwelcome findings and then buy his silence. The Chronicle of Higher Education 50,A26, http://www.chronicle.com/article/The-Price-of-Research/21691/.

Boone, M. D., C. A. Bishop, L. A. Boswell, et al. (2014). Pesticide regulation amid the influence of industry. Bioscience 64,917-922. 
525

526

527

528

529

530

531

532

533

534

535

536

537

538

539

540

541

542

543

544

545

546

547

Boone, M. D., S. M. James. (2003). Interactions of an insecticide, herbicide, and natural stressors in amphibian community mesocosms. Ecological Applications 13,829-841.

Boone, M. D., J. R. Rohr. (2015). The trouble with risk assessment lies at the foundation. Bioscience 65,227-228.

Civitello, D. J., J. Cohen, H. Fatima, et al. (2015). Biodiversity inhibits parasites: Broad evidence for the dilution effect. Proceedings of the National Academy of Sciences of the United States of America 112,8667-8671.

Clements, W. H., J. R. Rohr. (2009). Community responses to contaminants: Using basic ecological principles to predict ecotoxicological effects. Environmental Toxicology and Chemistry 28,1789-1800.

Cohen, J. M., D. J. Civitello, A. J. Brace, et al. (2016). Spatial scale modulates the strength of ecological processes driving disease distributions. Proceedings of the National Academy of Sciences of the United States of America 113,E3359-E3364.

Dalton, R. (2010). E-mails spark ethics row. Nature 466.

De Laender, F., J. R. Rohr, R. Ashauer, et al. (2016). Re-introducing environmental change drivers in biodiversity-ecosystem functioning research. Trends in Ecology and Evolution 12,905-915.

de Noyelles, F., W. D. Kettle, C. H. Fromm, et al. (1989). Use of experimental ponds to assess the effects of a persticide on the aquatic environment. Pages 41-56 in J. R. Voshell, editor. Using mesocosms to assess the aquatic ecological risk of pesticides: theory and practice. Entomological Society of America, Lanham, MD.

Dobson, A., I. Cattadori, R. D. Holt, et al. (2006). Sacred cows and sympathetic squirrels: the importance of biological diversity to human health. Plos Medicine 3,714-718. 
Douglas, M. R., J. R. Rohr, J. F. Tooker. (2015). Neonicotinoid insecticide travels through a soil food chain, disrupting biological control of non-target pests and decreasing soya bean yield. Journal of Applied Ecology 52,250-260.

Ehrsam, M., S. A. Knutie, J. R. Rohr. (2016). The herbicide atrazine induces hyperactivity and compromises tadpole detection of predator chemical cues. Environmental Toxicology and Chemistry 35,2239-2244.

Fan, W. Q., T. Yanase, H. Morinaga, et al. (2007). Atrazine-induced aromatase expression is SF1 dependent: Implications for endocrine disruption in wildlife and reproductive cancers in humans. Environmental Health Perspectives 115,720-727.

Farruggia, F. T., C. M. Rossmeisl, J. A. Hetrick, et al. (2016). Refined Ecological Risk Assessment for Atrazine. US Environmental Protection Agency, Office of Pesticide Programs, Washington, D.C.

Forson, D., A. Storfer. (2006a). Effects of atrazine and iridovirus infection on survival and lifehistory traits of the long-toed salamander (Ambystoma macrodactylum). Environmental Toxicology and Chemistry 25,168-173.

Forson, D. D., A. Storfer. (2006b). Atrazine increases ranavirus susceptibility in the tiger salamander, Ambystoma tigrinum. Ecological Applications 16,2325-2332.

Gabor, C. R., E. A. Roznik, S. A. Knutie, et al. (2016). Does corticosterone mediate the negative effects of atrazine and Batrachochytrium dendrobatidis on growth and survival? Integrative and Comparative Biology 56,E70-E70.

Gendron, A. D., C. A. Bishop, R. Fortin, et al. (1997). In vivo testing of the functional integrity of the corticosterone-producing axis in mudpuppy (amphibia) exposed to chlorinated hydrocarbons in the wild. Environmental Toxicology and Chemistry 16,1694-1706. 
571 Grube, A., D. Donaldson, T. Kiely, et al. (2011). Pesticide industry sales and usage: 2006 and

572

573

574

575

576

577

578

579

580

581

582

583

584

585

586

587

588

589

590

591

592 2007 market estimates. U.S. Environmental Protection Agency, Washington, D.C.

Halstead, N., C. Hoover, A. Arakala, et al. (2017). Agrochemical pollution increases risk of human exposure to schistosome parasites. Biorxiv 161901.

Halstead, N. T., T. A. McMahon, S. A. Johnson, et al. (2014). Community ecology theory predicts the effects of agrochemical mixtures on aquatic biodiversity and ecosystem properties. Ecology Letters 17,932-941.

Hayes, T., K. Haston, M. Tsui, et al. (2002a). Herbicides: Feminization of male frogs in the wild. Nature 419,895-896.

Hayes, T., K. Haston, M. Tsui, et al. (2003). Atrazine-induced hermaphroditism at $0.1 \mathrm{ppb}$ in American leopard frogs (Rana pipiens): Laboratory and field evidence. Environmental Health Perspectives 111,568-575.

Hayes, T. B. (2003). Alteration of the hormonal milieu following atrazine exposure: What do amphibian studies tell us about humans? Biology of Reproduction 68,103-103.

Hayes, T. B. (2004). There is no denying this: Defusing the confusion about atrazine. Bioscience $\mathbf{5 4 , 1 1 3 8 - 1 1 4 9 . ~}$

Hayes, T. B., P. Case, S. Chui, et al. (2006). Pesticide mixtures, endocrine disruption, and amphibian declines: Are we underestimating the impact? Environmental Health Perspectives 114,40-50.

Hayes, T. B., A. Collins, M. Lee, et al. (2002b). Hermaphroditic, demasculinized frogs after exposure to the herbicide atrazine at low ecologically relevant doses. Proceedings of the National Academy of Sciences of the United States of America 99,5476-5480. 
Hayes, T. B., V. Khoury, A. Narayan, et al. (2010). Atrazine induces complete feminization and chemical castration in male African clawed frogs (Xenopus laevis). Proceedings of the National Academy of Sciences of the United States of America 107,4612-4617.

Herman, D., N. K. Kaushik, K. R. Solomon. (1986). Impact of Atrazine on Periphyton in FreshWater Enclosures and Some Ecological Consequences. Canadian Journal of Fisheries and Aquatic Sciences 43,1917-1925.

Howard, C. (2013a). Pest Control: Syngenta's Secret Campaign to Discredit Atrazine's Critics. Pages https://100r.org/2013/2006/pest-control-syngentas-secret-campaign-to-discreditatrazines-critics/ in 100Reporters, editor.

Howard, C. (2013b). Tillery to Represent Hayes Against UC Berkeley in Dispute over Lab Fees. Pages https://100r.org/2013/2008/excessive-lab-fees-choking-research-scientist-says/ in 100Reporters, editor.

Ivory, D. (2009). EPA Fails To Inform Public About Weed-Killer In Drinking Water. The Huffington Post,http://www.huffingtonpost.com/2009/2008/2023/epa-fails-to-informpubli_n_266686.html.

Ivory, D. (2010). Is Weed Killer in Drinking Water Dangerous? Govt. Is Letting the Chemical Industry Come Up with the Answer.in Alternet.org, editor.

Kerby, J. L., A. Storfer. (2009). Combined effects of atrazine and chlorpyrifos on susceptibility of the tiger salamander to Ambystoma tigrinum virus. EcoHealth 6,91-98.

Kiesecker, J. M. (2002). Synergism between trematode infection and pesticide exposure: A link to amphibian limb deformities in nature? Proceedings of the National Academy of Sciences of the United States of America 99,9900-9904. 
615

616

617

618

619

620

621

622

623

624

625

626

627

628

629

630

631

632

633

634

635

Knutson, M. G., W. B. Richardson, D. M. Reineke, et al. (2004). Agricultural ponds support amphibian populations. Ecological Applications 14,669-684.

Koprivnikar, J. (2010). Interactions of environmental stressors impact survival and development of parasitized larval amphibians. Ecological Applications 20,2263-2272.

Landis, W. G., J. R. Rohr, S. J. Moe, et al. (2014). Global Climate Change and Contaminants, a Call to Arms Not Yet Heard? Integrated Environmental Assessment and Management 10,483-484.

Langerveld, A. J., R. Celestine, R. Zaya, et al. (2009). Chronic exposure to high levels of atrazine alters expression of genes that regulate immune and growth-related functions in developing Xenopus laevis tadpoles. Environmental Research 109,379-389.

Larson, D. L., S. McDonald, A. J. Fivizzani, et al. (1998). Effects of the herbicide atrazine on Ambystoma tigrinum metamorphosis: Duration, larval growth, and hormonal response. Physiological Zoology 71,671-679.

Li, Y., J. M. Cohen, J. R. Rohr. (2013). Review and synthesis of the effects of climate change on amphibians. Integrative Zoology 8,145-161.

Liu, X., J. R. Rohr, Y. M. Li. (2013). Climate, vegetation, introduced hosts and trade shape a global wildlife pandemic. Proceedings of the Royal Society B-Biological Sciences 280.

Lurling, M., M. Scheffer. (2007). Info-disruption: pollution and the transfer of chemical information between organisms. Trends in Ecology \& Evolution 22,374-379.

Madliger, C. L., S. J. Cooke, E. J. Crespi, et al. (2016). Success stories and emerging themes in conservation physiology. Conservation Physiology 4. 
Martin, L. B., W. A. Hopkins, L. D. Mydlarz, et al. (2010). The effects of anthropogenic global changes on immune functions and disease resistance. Pages 129-148 Year in Ecology and Conservation Biology 2010.

McMahon, T. A., R. K. Boughton, L. B. Martin, et al. (2017). Exposure to the herbicide atrazine nonlinearly affects tadpole corticosterone levels. Journal of Herpetology 52,270-273.

McMahon, T. A., N. T. Halstead, S. Johnson, et al. (2011). The fungicide chlorothalonil is nonlinearly associated with corticosterone levels, immunity, and mortality in amphibians. Environmental Health Perspectives 119,1098-1103.

McMahon, T. A., N. T. Halstead, S. Johnson, et al. (2012). Fungicide-induced declines of freshwater biodiversity modify ecosystem functions and services. Ecology Letters $15,714-722$.

McMahon, T. A., J. M. Romansic, J. R. Rohr. (2013). Nonmonotonic and monotonic effects of pesticides on the pathogenic fungus Batrachochytrium dendrobatidis in culture and on tadpoles. Environmental Science \& Technology 47,7958-7964.

McMahon, T. A., B. F. Sears, M. D. Venesky, et al. (2014). Amphibians acquire resistance to live and dead fungus overcoming fungal immunosuppression. Nature 511,224-227.

Michaels, D., C. Monforton. (2005). Manufacturing uncertainty: Contested science and the protection of the public's health and environment. American Journal of Public Health 95,S39-S48.

Moore, A., C. P. Waring. (1998). Mechanistic effects of a triazine pesticide on reproductive endocrine function in mature male Atlantic salmon (Salmo salar L.) parr. Pesticide Biochemistry and Physiology 62,41-50. 
658

659

660

661

662

663

664

665

666

667

668

669

670

671

672

673

674

675

676

677

678

679

Polansek, T. (2016). Widely used U.S. farm chemical atrazine may threaten animals: EPA. Pages http://www.reuters.com/article/us-usa-epa-atrazine-idUSKCNOYO2X9 Reuters, http://www.reuters.com/article/us-usa-epa-atrazine-idUSKCNOYO2X9.

Raffel, T. R., N. T. Halstead, T. McMahon, et al. (2013). Disease and thermal acclimation in a more variable and unpredictable climate. Nature Climate Change 3,146-151.

Raffel, T. R., J. T. Hoverman, N. T. Halstead, et al. (2010). Parasitism in a community context: Trait-mediated interactions with competition and predation. Ecology 91,1900-1907.

Raffel, T. R., J. L. Sheingold, J. R. Rohr. (2009). Lack of pesticide toxicity to Echinostoma trivolvis eggs and miracidia. Journal of Parasitology 95,1548-1551.

Rohr, J. R., D. J. Civitello, P. W. Crumrine, et al. (2015). Predator diversity, intraguild predation, and indirect effects drive parasite transmission. Proceedings of the National Academy of Sciences of the United States of America 112,3008-3013.

Rohr, J. R., P. W. Crumrine. (2005). Effects of an herbicide and an insecticide on pond community structure and processes. Ecological Applications 15,1135-1147.

Rohr, J. R., A. A. Elskus, B. S. Shepherd, et al. (2003). Lethal and sublethal effects of atrazine, carbaryl, endosulfan, and octylphenol on the streamside salamander, Ambystoma barbouri. Environmental Toxicology and Chemistry 22,2385-2392.

Rohr, J. R., A. A. Elskus, B. S. Shepherd, et al. (2004). Multiple stressors and salamanders: Effects of an herbicide, food limitation, and hydroperiod. Ecological Applications 14,1028-1040.

Rohr, J. R., N. T. Halstead, T. R. Raffel. (2012). The herbicide atrazine, algae, and snail populations. Environmental Toxicology and Chemistry 31,973-974. 
680

681

682

683

684

685

686

687

688

689

690

691

692

693

694

695

696

697

698

699

700

701

Rohr, J. R., P. Johnson, C. W. Hickey, et al. (2013a). Implications of global climate change for natural resource damage assessment, restoration, and rehabilitation. Environmental Toxicology and Chemistry 32,93-101.

Rohr, J. R., J. L. Kerby, A. Sih. (2006a). Community ecology as a framework for predicting contaminant effects. Trends in Ecology \& Evolution 21,606-613.

Rohr, J. R., K. A. McCoy. (2010a). Preserving environmental health and scientific credibility: A practical guide to reducing conflicts of interest. Conservation Letters 3,143-150.

Rohr, J. R., K. A. McCoy. (2010b). A qualitative meta-analysis reveals consistent effects of atrazine on freshwater fish and amphibians. Environmental Health Perspectives 18,20-32.

Rohr, J. R., B. D. Palmer. (2005). Aquatic herbicide exposure increases salamander desiccation risk eight months later in a terrestrial environment. Environmental Toxicology and Chemistry 24,1253-1258.

Rohr, J. R., B. D. Palmer. (2013). Climate change, multiple stressors, and the decline of ectotherms. Conservation Biology 27,741-751.

Rohr, J. R., T. R. Raffel. (2010). Linking global climate and temperature variability to widespread amphibian declines putatively caused by disease. Proceedings of the National Academy of Sciences of the United States of America 107,8269-8274.

Rohr, J. R., T. R. Raffel, A. R. Blaustein, et al. (2013b). Using physiology to understand climatedriven changes in disease and their implications for conservation. Conservation Physiology 1,doi:10.1093/conphys/cot1022.

Rohr, J. R., T. R. Raffel, C. A. Hall. (2010). Developmental variation in resistance and tolerance in a multi-host-parasite system. Functional Ecology 24,1110-1121. 
Rohr, J. R., T. R. Raffel, N. T. Halstead, et al. (2013c). Early-life exposure to a herbicide has enduring effects on pathogen-induced mortality. Proceedings of the Royal Society BBiological Sciences 280,20131502.

Rohr, J. R., T. R. Raffel, J. M. Romansic, et al. (2008a). Evaluating the links between climate, disease spread, and amphibian declines. Proceedings of the National Academy of Sciences of the United States of America 105,17436-17441.

Rohr, J. R., T. R. Raffel, S. K. Sessions, et al. (2008b). Understanding the net effects of pesticides on amphibian trematode infections. Ecological Applications 18,1743-1753.

Rohr, J. R., T. Sager, T. M. Sesterhenn, et al. (2006b). Exposure, postexposure, and densitymediated effects of atrazine on amphibians: Breaking down net effects into their parts. Environmental Health Perspectives 114,46-50.

Rohr, J. R., C. J. Salice, R. M. Nisbet. (2016). The pros and cons of ecological risk assessment based on data from different levels of biological organization. Critical Reviews in Toxicology 46,756-784.

Rohr, J. R., C. J. Salice, and R. M. Nisbet. (2017). Chemical safety must extend to ecosystems. Science 356,917-917.

Rohr, J. R., A. M. Schotthoefer, T. R. Raffel, et al. (2008c). Agrochemicals increase trematode infections in a declining amphibian species. Nature 455,1235-1239.

Rohr, J. R., T. M. Sesterhenn, C. Stieha. (2011). Will climate change reduce the effects of a pesticide on amphibians?: Partitioning effects on exposure and susceptibility to pollution. Global Change Biology 17,657-666.

Rohr, J. R., A. Swan, T. R. Raffel, et al. (2009). Parasites, info-disruption, and the ecology of fear. Oecologia 159,447-454. 
725

726

727

728

729

730

731

732

733

734

735

736

737

738

739

740

741

742

743

744

745

Sass, J. B., A. Colangelo. (2006). European Union bans atrazine, while the United States negotiates continued use. International Journal of Occupational and Environmental Health 12,260-267.

Sass, J. B., J. P. Devine. (2004). The center for regulatory effectiveness invokes the data quality act to reject published studies on atrazine toxicity. Environmental Health Perspectives 112,A18-A18.

Schor, E. (2010). Enviro Groups Cheer as Scientist Bombards Agribusiness With Profane EMails. Pages http://www.nytimes.com/gwire/2010/2008/2026/2026greenwire-envirogroups-cheer-as-scientist-bombards-agri-18199.html?pagewanted=all The New York Times. E\&E Publishing, New York.

Schotthoefer, A. M., J. R. Rohr, R. A. Cole, et al. (2011). Effects of wetland vs. landscape variables on parasite communities of Rana pipiens: links to anthropogenic factors. Ecological Applications 21,1257-1271.

Sears, B. F., P. W. Snyder, J. R. Rohr. (2013). Infection deflection: hosts control parasite location with behaviour to improve tolerance. Proceedings of the Royal Society BBiological Sciences $\mathbf{2 8 0 .}$

Sears, B. F., P. W. Snyder, J. R. Rohr. (2015). Host life history and host-parasite syntopy predict behavioural resistance and tolerance of parasites. Journal of Animal Ecology 84,625-636.

Slater, D. (2012). The Frog of War. Mother Jones January/February,http://www.motherjones.com/environment/2011/2011/tyrone-hayesatrazine-syngenta-feud-frog-endangered. 
Solomon, K. R., J. A. Carr, L. H. Du Preez, et al. (2008). Effects of Atrazine on Fish, Amphibians, and Aquatic Reptiles: A Critical Review. Critical Reviews in Toxicology 38,721-772.

Spegele, B., K. Chu. (2016). ChemChina-Syngenta \$43 Billion Deal Approved by U.S. Security Panel. Pages http://www.wsj.com/articles/u-s-security-watchdog-clears-43-billionchemchina-syngenta-takeover-deal-1471844896 The Wall Street Journal, New York.

Staley, Z., V. J. Harwood, J. R. Rohr. (2010). The effect of agrochemicals on indicator bacteria densities in outdoor mesocosms. Environmental Microbiology 12,3150-3158.

Staley, Z. R., V. J. Harwood, J. R. Rohr. (2015). A synthesis of the effects of pesticides on microbial persistence in aquatic ecosystems. Critical Reviews in Toxicology 45,813-836.

Staley, Z. R., J. R. Rohr, V. J. Harwood. (2011). Test of direct and indirect effects of agrochemicals on the survival of fecal indicator bacteria. Applied and Environmental Microbiology 77,8765-8774.

Staley, Z. R., J. R. Rohr, J. K. Senkbeil, et al. (2014). Agrochemicals indirectly increase survival of E. coli O157:H7 and indicator bacteria by reducing ecosystem services. Ecological Applications 24,1945-1953.

Staley, Z. R., J. K. Senkbeil, J. R. Rohr, et al. (2012). Lack of direct effects of agrochemicals on zoonotic pathogens and fecal indicator bacteria. Applied and Environmental Microbiology 78,8146-8150.

Storrs, S. I., J. M. Kiesecker. (2004). Survivorship patterns of larval amphibians exposed to low concentrations of atrazine. Environmental Health Perspectives 112,1054-1057. 
Tierney, K. B., C. R. Singh, P. S. Ross, et al. (2007). Relating olfactory neurotoxicity to altered olfactory-mediated behaviors in rainbow trout exposed to three currently-used pesticides. Aquatic Toxicology 81,55-64.

USEPA. (2012). Meeting of the FIFRA Scientific Advisory Panel on the Problem Formulation for the Environmental Fate and Ecological risk Assessment for Atrazine. US Environmental Protection Agency.

Vandenberg, L. N., T. Colborn, T. B. Hayes, et al. (2012). Hormones and endocrine-disrupting chemicals: low-dose effects and nonmonotonic dose responses. Endocrine Reviews $33,378-455$.

Venesky, M. D., X. Liu, E. L. Sauer, et al. (2014a). Linking manipulative experiments to field data to test the dilution effect. Journal of Animal Ecology 83,557-565.

Venesky, M. D., T. R. Raffel, T. A. McMahon, et al. (2014b). Confronting inconsistencies in the amphibian-chytridiomycosis system: implications for disease management. Biological Reviews 89,477-483.

Wake, D. B., V. T. Vredenburg. (2008). Are we in the midst of the sixth mass extinction? A view from the world of amphibians. Proceedings of the National Academy of Sciences of the United States of America 105,11466-11473.

Welshons, W. V., K. A. Thayer, B. M. Judy, et al. (2003). Large effects from small exposures. I. Mechanisms for endocrine-disrupting chemicals with estrogenic activity. Environmental Health Perspectives 111,994-1006. 


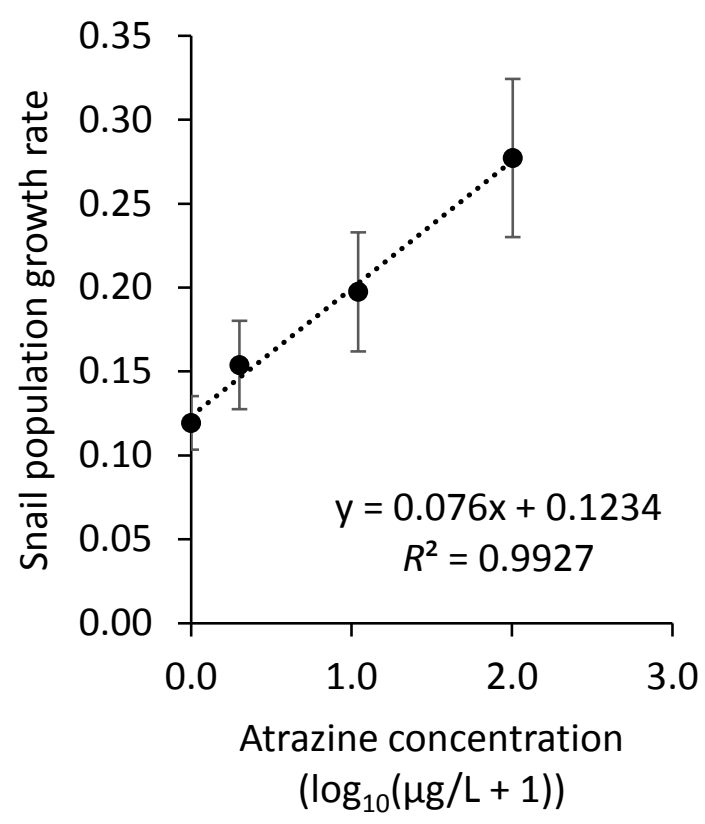

788 Fig. 1. The population growth rate of snails in outdoor mesocosms containing $0,1,10,100 \mu \mathrm{g} / \mathrm{L}$ 789 of atrazine in the Syngenta-funded study by Baxter et al. (2011). Growth rates are calculated for 790 the exponential phase until a carrying capacity or decline in growth occurred. The $30 \mu \mathrm{g} / \mathrm{L}$ 791 treatment was excluded because it did not show the same spatial blocking patterns in dissolved 792 oxygen as the other treatments (see Rohr et al. 2012). 